\title{
The Use of Social Media and Participation in Political Communication in the 2019 General Election in Nigeria
}

\author{
By Dr. Emmanuel Ufuophu-Biri, \\ Associate Professor of Mass Communication and Journalism, \\ Head of Department, Mass Communication \& Director, Pre - Degree Programme \\ Delta State University, Abraka, Nigeria
}

\begin{abstract}
Bibliographical Notes
Dr Emmanuel Ufuophu-Biri is an Associate Professor of Mass Communication and Journalism at Delta State University, Abraka, Nigeria; former Head of Department of Mass Communication and the current Director, Pre - Degree Programme in same University. He holds PhD in Communication Arts, MA (Distinction) Mass Communication, Master's Degree in Industrial and Labour Relations, B.A. Mass Communication, Diploma and Advanced Diploma in Journalism, Certificate in TV Production and Certificate in Digital Humanities, Brown University, Providence, USA. He is an Alumnus of the Brown University International Advanced Research Institute, Providence, USA and the USA International Visitors' Leadership Program (IVLP), USA. He is interested in print and broadcast journalism, development communication and digital media.
\end{abstract}

DOI: $10.7176 / \mathrm{IKM} / 10-3-03$

Publication date: April $30^{\text {th }} 2020$

\begin{abstract}
Research findings have shown that the social media are very active in promotion of citizens' participation in political and electoral procession in many countries. However, the Nigerian voters before the advent of the social media have been mainly receivers of information on election without being active participants in the electoral information flow. The voters did not have access to the mainstream media which had hitherto been the main conveyors of electoral information. Therefore, the purpose of the study is to examine how the electorate in Delta State, Nigeria used the social media for participation in political communication during the 2019 Nigerian general elections. The study is guided by the Technological Acceptance Model which explains how users come to accept and use a technology. The study used survey and questionnaire as method and instrument respectively to gather the data. We used both simple random sampling technique and purposive sampling technique. The data were analyzed using descriptive statistics. The results show that the voters are highly exposed to political communication in the social media; they have favourable perception of the social media usage for political communication; they prefer the social media to the mainstream media in participation in political communication; and they participate more actively in political communication during the said election through the social media more than they did previous elections through the mainstream media. We recommend that that the voters should sustain their exposure to the use of the social media for political participation so that can also be kept abreast of the happenings in the political terrain and they should continue to use the social media to interrogate political leaders, election candidates during elections and after the election period.
\end{abstract}

Keywords: Silenced electorate; Nigerian general elections; social media and elections; political participation; participation in political communication, participation in political discourse.

\section{Introduction}

Elections in Nigeria are taken very seriously by all the stakeholders. The stakeholders include political parties, candidates, the electorate, the electoral umpire, government, law enforcement agencies and organized civil societies. The various political parties and political contestants engage in intensive political campaigns mainly through the mainstream media and other forms of interpersonal communication. Before the adoption of the social media for political communication, political communication had largely been a one way communication basically from the political contestants, political parties, government and the election umpire to the electorate. The electorate had limited or no means of talking back to the politicians. Okoro and Kenneth (2013 discloses that the voters were rather silenced and unable to give feedback to the political communication. Similarly Biswas, Ingle and Roy (2014) explain that the voters were largely not participating in the political communication process and discourse. Sauter and Bruns (2013) write that the major means of mass communicating with the voters before the use of the social media was through the mainstream media of newspaper, magazine, radio and television. These media houses only paid attention to the political gladiators and the election umpires without given adequate opportunity to the voters to participate in the political discourse.

The use of the mainstream media is expensive and largely beyond the financial reach of most voters. The voters, according to Dagona, Karick and Abubakar (2013), became mere consumers of the information from the political gladiators. The voters could not even participate in horizontal communication among themselves. 
However, the use of the social media has given voice to the voters to participate in political communication. However, the advent of the social media seems to have given voice to the electorate. Supporting this assertion, Egwemi (2013) explains that the social media have become formidable and reliable source of political communication which is accessible to both the politicians and the electorate. According to Fenton and Barassi (2011) research findings indicate that the social media have provided a powerful alternative to the mainstream media in political communication and political marketing.

The social media could provide the voters the much needed opportunity to participate effectively in political and electioneering discourse during election. Through the social media, the voters can respond to political discourse, initiate political discussion, interrogate political issues, communicate massively with political gladiators and discuss horizontally among themselves. The social media have liberated the voters from political silence and given them the opportunity to participate in political discourse or communication as has never been before the use of social media for the purpose of political communication. The voters have become very active in political discourse on the platform of the social media (Fenton and Barassi, 2011; Johansson, 2019).

The 2019 general elections in Nigeria were held in the first quarter of 2019. The elections covered the presidential election, the National Assembly election, the governorship and state houses of assembly election. Bello, Inuwa-Dutse and Heckel (2019) found that all the different stakeholders in the election used the social media. The social media were used to disseminate information by the political gladiators, the election umpires and the electorate. While the political candidates and their political parties used the social media to canvass for votes and to sell their manifestoes, the voters used the social media to interrogate the candidates, the political parties, the election umpire (the Independent National Electoral Commission). Biswas, Ingle and Roy (2014) assert that the social media seem to have made the voters in Nigeria very active in political discourse during the 2019 general elections. The social media thus un-silenced them and gave them a voice to participate in the political discourse. The study thus interrogates how the electorate use the social media to participate in political communication during the 2019 general election in Nigeria. In the context of this study, participation in political communication refers the communication between the politicians and the electorate during election which is basically campaign messages and the feedback from the electorate. It also refers to the communication among the voters as pertain to election messages. It has to do the politicians and the electorate participating actively in political and electoral discourse through the social media and the mainstream media.

\subsection{Statement of the Problem}

The mass media are known to play significant role in the electioneering process in any country. In Nigeria, the mass media are very useful during election. They are the major source of information and communication. Before recent times, they were at the exclusive use and disposal of the political contestants, political parties, the government and the election umpire. However, the social media seem to have altered this routine. The social media are open to all stakeholders in an election and do not require the huge amount of money required before using the mainstream media. Also, they are easy to use and much cheaper and accessible. Garrett (2019) posits that right from the 2008 presidential election in the United States of America, the use of the social media for election has become an accepted global phenomenon. The voters have come to take full advantage of the social media and use them effectively in different ways during political discourse. However, there is dearth of empirical data on the level of acceptance and use of the social media for election by the electorate in Delta State, Nigeria. There is also lacuna on how the voters in Delta State use the social media for election purpose, especially during the 2019 general election in Nigeria. Additionally, there is the need to ascertain scientifically, the electorate's perception of the social media as an active alternative voice for election purpose. The following research questions guided the study.

\subsubsection{Research Questions}

(1) What is the level of exposure of the electorate in Delta State to political communication in the social media during the 2019 general election in Nigeria?

(2) How do voters in Delta State perceive the social media as a source of formidable alternative voice during the 2019 general election in Nigeria?

(3) What is the preference pattern of the electorate in Delta State for political communication through the mainstream media and social media during the 2019 general election in Nigeria?

(4) What is the level of participation of the electorate in Delta State through the social media in the 2019 general election?

(5) What is the level of participation of voters in Delta State in political communication through the social media in the 2019 general election compared to their political communication through the mainstream media in previous elections?

\subsection{Literature Review}

The social media have become very popular across the world with respect to their usage for political 
communication, political marketing, and political electioneering process and electorate participation in political election discourse. Arshad and Hassan (2014) write that many people in different countries of the world have become very much aware of the importance of the social media for electioneering purpose. Indeed, they are highly exposed to political communication that is carried in the social media. Biswas, Ingle and Roy (2014) found that since the election of President Barack Obama in the US, many voters have become very exposed to the social media. Golan, Arceneaux and Soule (2019) found that most voters are exposed to political communication that are carried by the social media.

Politicians have taken largely to the social media where they get their political messages and persuasions to the electorate. Both the electorate and the politicians, according to Ezeah and Gever (2015) have taken cognizance of the immense opportunity the social media offers in terms of exposing the voters to the political messages of the politician as well as getting the feedback of the electorate to the politicians. Communication between the politicians and the voters have been simplified, demystified and democratized through the use of the social media. A study on social media use for expression of political views in Nigeria by Ugwuanyi, Olijo and Gever (2019) found that many voters in Nigeria used the social media to communicate with politicians and among themselves for electioneering purpose during the 2019 general election in Nigeria. Ohme, de Vreese and Albaek (2017) found that politicians and electorate are highly exposed to the use of social media for political marketing, political communication, political persuasion and elections generally. Scholars including Adegbola and Gearhart (2019), Assibong and Oshanisi (2018), Ayeni and Esan (2018), Kahnea and Middaugh (2012) found that politicians and the electorate are sufficiently exposured to political communication and discourse in the social media.

Apart from the exposure to the social media, the electorate's perception of the social media as tool for political communication during election also matters. Garrett (2019) found that social media such as Facebook and Twitter promote misconception during political campaigns. The social media sometimes promote false endorsement of candidates and consequently create misconception among the voters. The voters are regularly exposed to deceptive political messages during election. Such a situation could create wrong perception about the social media as some could regard them as conveyors of false and deceptive political messages (Tandoc, Lim, and Ling, 2018). However, Okoro and Tsegyu (2019) found that the voters, despite the seemingly hate messages and pernicious propaganda carried in the social media during the 2011 presidential election in Nigeria, the electorate had positive perception of the social media. The positive perception, according to Chijoke (2013) could be attributed to the voters' sense of freedom as provided by the social media which enabled the voters to participate in the political discourse during the election. Dalton (2009) reports that President Barack Obama used the social media effectively during the US 2008 presidential election. President Obama used the social media to appeal to the American electorate, especially the youths and to get their votes. The voters subsequently developed positive perception for the social media. Since 2008 politicians and the voters have realized the capability and viability of the social media as a reliable means to reach to the electorate and for the electorate to have an unsuppressed voice in the discourse of the political and electioneering process. The people's realization of the power of the social media for political communication could help to shape the voters' perception positively for the use of the social media for election matters (Galloway and Guthrie, 2010; Bode, Vraga, Borah and Shah, 2014; Siluveru, 2015 and Stroud, 2008).

Van Dijck (2013) explains that the social media, especially Facebook, Twitter and Youtube have become powerful vehicles of political campaign. The different stakeholders in election use them. This according to Ingram (2018) demonstrates that the voters have positive perception of the social media use for election. This positive perception enables politicians to get in touch personally with the members of their constituencies. The voters also prefer the political communication in the social media because the social media provide an interactive platform for both the politicians and electorate to interact with each other at minimal cost and ease. The social media could provide effective alternative voice politically for the voters and the politicians. They could easily access the social media and use them with ease and without restrictions or bottle neck bureaucracy (Ingram, 2018).

The voters are also afforded the opportunity of talking back to the politicians as well as discussing among themselves (Hindman, 2018; Gottfried and Barthel, 2018). The voters as studies indicate, since the USA presidential election of 2016, have become fatigued with the regular barrage of political news and other forms of political communication carried in the mainstream media. Rather they have found solace, alternative voice and preference in the social media (Gottfried and Barthe, 2018 and Rohlinger and Bunnage, 2017). Brants and Voltmer (2011) posits that there has been significant change in pattern of political communication since the adoption of social media for political communication. The social media provides more opportunities for both the politicians and the electorate during election.

In line with the view of Voltmer (2011), other scholars such as Udeajah and Gever (2015), Nwanton, Odoemalamm, Orji-Egwu, Nwankwo and Nweze (2013) and Okoro and Santas (2017) found that several research findings have shown that many voters currently use the social media for political participation and 
electioneering discourse. Kushin and Kitchener (2009) note that in the past voters had difficulties in sending their stories or expressions to the mainstream media and even if they are were able to send them, the mainstream media published only what they want to publish.

Before the adoption of the social media for election matters voters had difficulty appearing on radio or television to make their contributions to election or political discuss. The social media have created the possible and favourable atmosphere for the voters to participate in political discourse from anywhere they are. Through the social media they could participate in political and electioneering discourse from the comfort of their bedrooms, offices, on transit or in any other place they are. Sometimes they participate in political communication through social media groups as WhatsApp, Facebook, Twitter and Instagram. (Zhang, Johnson, Seltzer, Bichard, 2010; Yardi and Boyd, 2010; Larsson and Moe 2011)

Fenton (2011) shares similar views with the above cited authorities and states that through such group interaction the voters are able to interrogate the politicians, engage the politicians on one-on-one discussions and fact finding. Social media such as Facebook also provide platform for the voters to discuss political and election issues among themselves. The era of people who had access to the mainstream media being regarded as the super opinion shapers and leaders has largely gone into extinction. Adegbola and Gearhart (2019) posit that the advent of the social media has given voters the accessibility to sufficient, credible and authoritative political information which enable them to form their independent opinions and for their voices to be heard. The social media also afford the voters the opportunity to be opinion leaders without relying on the information from those who were hitherto regarded as opinion leaders before the adoption and deployment for political communication (Okeke, Chinonye and Obi, 2016).

The voters could engage in mass political communication through WhatsApp, Twitter, Facebook and Instagram and could ask questions and make their own comments. Their comments could reach several other voters and help to shape their opinions about the voting patterns and choice of candidates. Consequently, voters are able to discuss among themselves thus jettisoning the era of only people who had access to the mainstream media becoming the super opinion shapers. Wattal, Schuff, Mandviwalla, and Williams (2010) explain that the voters in modern times are no longer passive but very active participants in political discussions and their political discussions help to shape the direction of political voting. Zeng, Chen, Lusch, Li (2010) explain that the era of political passivity by the electorate is gone. As a result of the social media the voters have developed keen interest in political communication. Emmer and Kunst (2018) posit that politicians and voters tends to prefer the social media to the mainstream media because politicians can easily use the social media to inform voters of the politicians' manifesto and the voters also respond very quickly. The social media create a fast and seamless means of political communication between the politicians and the voters.

The voters seem to have become active in political discourse. They had difficulty in getting their views to the mainstream media (Fenton, 2011). Additionally, the mainstream media have limited space and broadcast time thus the media have to be very selective in what fills the limited space and time. With the social media, which are easily accessible to anybody who has telephone and internet connectivity political participation has become very easy. Any voter who has telephone handset and internet connectivity could participate actively in political discourse (Dagona, Karick and Abubakar, 2013).

According to Freedom House (2017), the social media have provided opportunity for people participate in political discussions more than they did before the use of the social media for political communication. The political communication atmosphere has been changed by the emergence and adoption of the social media to the extent that every voter could now participate in political communication. There is no more restriction on political communication, a situation that has created a sort of media democratization, liberalization and deregulation. The voters are thus able to participate in political communication and are now able to interrogate the politicians that are seeking their votes (Okeke, Chinonye and Obi, 2016). This has also led to some caution on the part of the politicians knowing that voters can evaluate them through social media engagement and form opinion that can have significant effect on the politicians' performance at the polls.

The 2011 presidential general election in Nigeria marked the first time that the social media were effectively deployed and used for the election campaigns. Since that election the voters in Nigeria have resorted to the use of social media for political participation and political communication (Dagona, et al, 2013). Furthermore, McAllister (2015) discloses that the social media have become formidable means of political communication in India, Pakistan and Bangladesh. The voters tend to prefer receiving political messages through the social media to receiving such information or message from the mainstream media. The social media have gained much popularity and acceptance to the extent that apart from using them for political discourse, political marketing and political communication, the voters use them for entertainment and other forms of social networking. Oyebode (2014) found that the social media provide the opportunity for voters to send and receive message from political office holders, politicians and political contestants. The social media enable them to express themselves on the social media and to other voters. The social media could create a scenario of political village square where political pundits and the electorate meet virtually to discuss political and election matters. 
Social status does not play any role in this political village square as any interest person could participate (Dagona, et al, 2013).

Adamu (2018) found that the social media provide opportunity for politicians to sell their qualities and manifestoes to the electorate. They are able to interact with the electorate directly through this virtual village square. The lack of symbiotic political communication between politicians and the electorate has been eradicated through the virtual village square created by the social media. Emruli and Bača (2011) posit that the social media provide two-way communication between politicians and voters. While politicians try to use the social media to change the perception of the voters and persuade them to get their votes during elections, the voters use the social media deliver feedbacks to the politicians. Biswas et al (2014) found that researches indicate that modern voting and election campaigns have depended largely on the technology of social media for effective communication of messages from the politicians to the electorate and feedback from the electorate to the politicians. In modern time a politician could put in a message into the social and immediately get feedback from the voters. The politician could also pass his or her manifesto to the voters who could also react immediately to the manifestoes on the social media.

Gerodimos and Justinussen (2014) found significant correlation between social media usage and political participation, political inclusiveness and political communication since Obama used the social media to campaign for his election 2008. Since the 2008 American presidential when Obama used the social media extensively for election campaign, politicians all over the world have adopted the use of the social media to seek the electorate's votes. The voters are no longer passive but very active in political communication. Their effective participation through the social media has created a virtual communication platform for both politicians and the voters to interact. Similarly, Chan (2016) extols the role of the social media as regard their use for election dialogue, political participation and electorate's involvement in political discourse and notes that the social media provides a veritable avenue to discover new voters. Social media provides a platform for politicians to engage in political dialogue with the voters. Such dialogue brings understanding between the politicians and the voters (Kalyango and Adu-Kumi, 2013).The social media thus provide ease of communication between the voters and the politicians.

However, Chadwick (2013) and (Van Dijck and Poell 2013) found that the use of social media for political communication has some disadvantages. One of such is lack of gate keeping. Anybody can post communication information in the social media without recourse to ethics of communication and legal issues. Gottfried and Barthel (2018) reports that the social media were fingered in creating misconception in the political discourse, perception and the voting pattern during the 2012 and 2016 USA presidential elections. DiFonzo, Beckstead, Stupak, and Walders (2016) also found that voters could develop negative perception for the social media usage for political communication because lack of adherence of social media users to ethical standards in public communication. Ugwuanyi, et al. (2019) found that the 2011 presidential election in Nigeria had several hate speeches on the social media. The different candidates attacked themselves using hate speech on the social media. Hate speeches and online bullying, according to Tesler and Zaller (2017) can lead to negative sentiments that can negatively influence voting pattern as well as lead to misrepresentation of fact.

The review shows the role the social media play in modern elections. The social media, as the review indicates, have provided opportunity for voters and politicians to engage themselves actively in political discourse. The social media seems to create a virtual meeting place for stakeholders in election to interact. The social media are regarded to have created an alternative voice and platform for the electorate to participate effectively in political communication.

\subsection{Theoretical Framework}

The study is anchored on the Technological Acceptance Model (TAM). The theory basically explains how users of information technology get to accept or reject a particular technology. The acceptance of the technology is fundamentally instrumental to its effective usage. It explains the reasons for the adoption and use of technology. The theory which was propounded by Fred Davis and Richard Bogozzi in 1989, holds that the acceptance and use of technology depend on Perceived Usefulness (PU) of the particular technology, perceived ease-of-use (PEOU) of the technology by the end user; and other external variables. The perceived usefulness as a determinant of the usage of technology is concerned with how the potential or real user of the technology perceives it to be of usefulness to him or her. If the perceived usefulness is high the individual is much more likely to accept and use the technology. However, if the perceived usefulness is low there is the likelihood of reluctance in using the technology or jettisoning it totally.

The perceived ease-of-use deals with how the individual perceives the easiness with which he or she could use the technology. The question here is whether the technology will be easy to use and to what positive significant extent it will improve his or her discharge of duties. If there is ease of use, the user easily accepts the technology and adopts it for use. External variables such as age, gender, educational status, income status and religion could also play a role in the acceptance and usage of technology. Supporting the postulations of TAM, 
Bagozzi (2007) explains that people could be reluctant to accept new technologies because of the technologies' complexity and element of uncertainty which exists in the minds of decision makers with respect to the successful adoption of the technology. The user has to know that the technology is useful and is easy to use before adopting it.

The decision to use the theory for this study is premised on the ground that the social media are relatively new compared to the age-long mainstream media. Additionally, the use of the social media for political discourse, communication and participation is new in the field of political communication. For the different stakeholders in politics and election to accept the use of the social media for the purpose of election, the basic tenets of the Technology Acceptance Model have to apply.

\subsection{Method}

Survey and questionnaire were used as the method and instrument to gather data for this study. The study covers the voting population of Delta State. We use simple random sampling to select three urban towns from each of the three senatorial districts in Delta State. We thereafter used the non-probability sampling technique to choose the actual respondents. We selected them purposively. One hundred and fifty respondents were selected randomly from each of the selected nine urban towns thus totally 1,350 respondents. We administered the instrument to only persons who said they voted in the 2019 general election. We also took cognizance of equity in gender and age bracket in the administration of the instrument. The town selected were Effurun, Sapele and Ughelli in Delta Central; Asaba, Agbor and Ogwashi-Uku in Delta North; and Koko, Bomadi and Ozoro in Delta South. We used the questionnaire to collect the data. With the aid of research assistants, we administered 1,350 copies of the questionnaire. A total of 1, 297 copies of the questionnaire were retrieved and analysed. This accounted for $96.07 \%$ return rate. We used descriptive method to analyse the data.

\subsection{Data Presentation, Analysis and Discussion}

Research question one: What is the level of exposure of the electorate in Delta State to political communication in the social media during the 2019 general election in Nigeria?

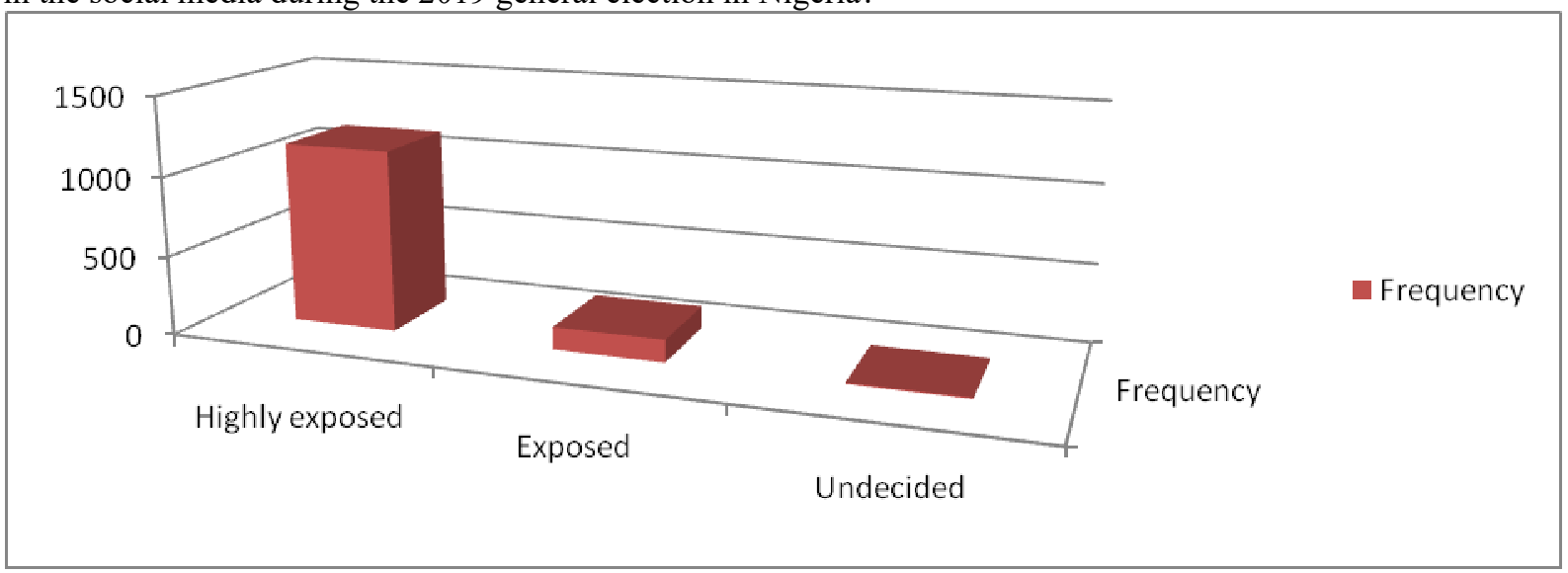

Figure 1: Respondents' exposure to political communication in the social media

Research question one sought to ascertain the level of the respondents' exposure to political communication in the social media. The result indicates that all the respondents were exposed to political communication in the social media during the 2019 general election in Nigeria. For instance 1147 (88. \%) respondents said they were highly exposed; $142(10.9)$ said that they were exposed while $8(.6 \%)$ remained neutral in their responses. Figure one above further provides graphic details of the respondents' exposure to political communication during the 2019 general election in Nigeria. We could therefore infer that majority of voters in Delta were exposed to political communication in the social media during the said election. This finding is reaffirms those of Kahnea and Middaugh (2012); Arshad and Hassan (2014); Mustapha, et al (2016), Ezeah and Gever (2015); Kim (2017); Adegbola and Gearhart (2019) and Golan, et al (2019) which hold that most voters are currently exposed to political communication in the social media.

Research question two: How do voters in Delta State perceive the social media as a source of formidable alternative voice during the 2019 general election in Nigeria? 


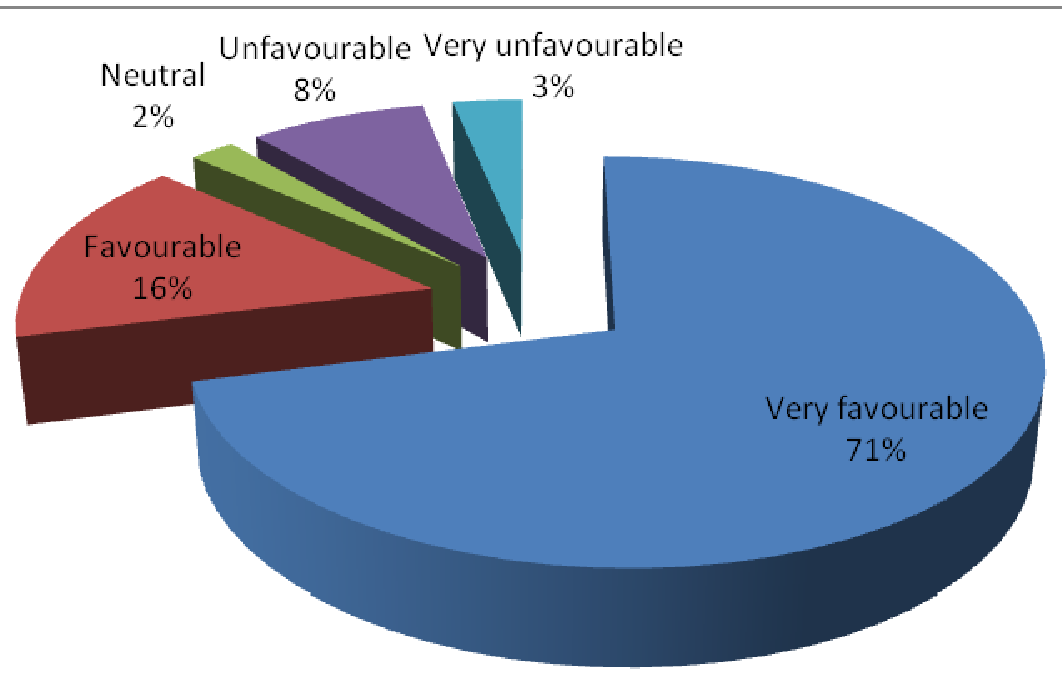

Figure 2: Respondents' perception of political communication in the social media

Research question two interrogated the respondents' perception of the social media as formidable alternative source of participation in political communication during the 2019 election in Nigeria. The result is presented in Figure 2 above. While responding to a Likert five scale items, $71.0 \%$ of the respondents said they had very favourable perception of the social media as formidable alternative source of political communication during the election. $16.0 \%$ said they had favourable perception of the social media usage for the purpose stated above. On the other hand, $2.0 \%$ said they had neutral perception. A total of $8.0 \%$ and $3.0 \%$ of the respondents had unfavourable and very unfavourable perception respectively of the social media as formidable alternative source for political communication during the said election. The implication of this result is that majority of the respondents have favourable perception of the social media use for political communication during the 2019 general election in Delta State. This result could also be generalized to all voters in Delta State because the sample for this study was selected to represent them. Furthermore, the result corroborate the earlier findings of Dalton (2009); Chijoke (2013); Okoro and Tsegyu (2019) and (Ugwuanyi, et al (2019). Their findings show that voters in modern day elections have favourable perception of the social media for political communication. However, the finding deviates from the those of Chadwick (2013); Van Dijck and Poell (2013); DiFonzo, et al (2016); Ugwuanyi, et al (2016) and Tesler and Zaller (2017) which postulate that many voters have negative perception of the social media usage for political communication.

Research question three: What is the preference pattern of the electorate in Delta State for political communication through the mainstream media and social media during the 2019 general election in Nigeria?

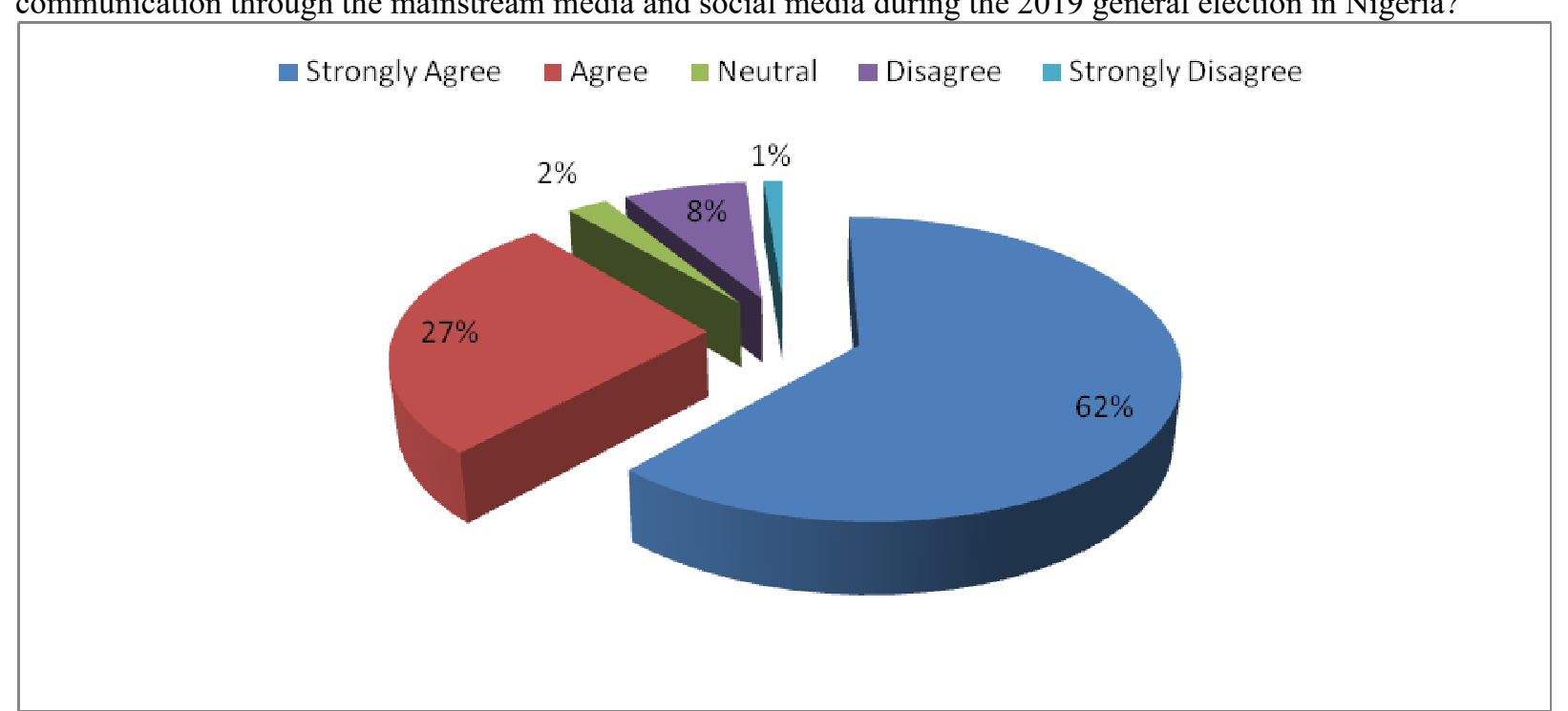

Figure 3: Respondents' preference for political communication in the mainstream media and social media Research question three sought to know the respondents' preference for either the social media or the 
mainstream media. Likert scale of five items was used to elicit the responses. The respondents were asked if they strongly agreed, agree, undecided, disagree or strongly disagree that they prefer the social media to the mainstream in political communication. The result as contained in Figure 3 show that majority of them responded that they prefer the use of the social media for political communication to use of the mainstream media for the same purpose. The breakdown of the result shows that $62 \%$ and $27 \%$ of the respondents strongly agreed and agreed respectively that they preferred the social media to the mainstream in usage for political communication. $2.0 \%$ was undecided while $8.0 \%$ and $1.0 \%$ of the respondents disagree and strongly disagree that they preferred the social media to the mainstream media for the said purpose. This implies that $89.0 \%$ of the respondents prefer the use of the social media to the mainstream media for political communication. We can therefore generalize that the voters in Delta State preferred the use of the social media to mainstream for political communication during the 2019 general elections. This finding agrees with those of Kalyango and Adu-Kumi, 2013); Gerodimos and Justinussen (2014); Chan (2016) and Kunst (2018). Their findings indicate that voters prefer to use the social media for political communication to using the mainstream media for the same purpose. Research question four: What is the level of participation of the electorate in Delta State through the social media in the 2019 general election?

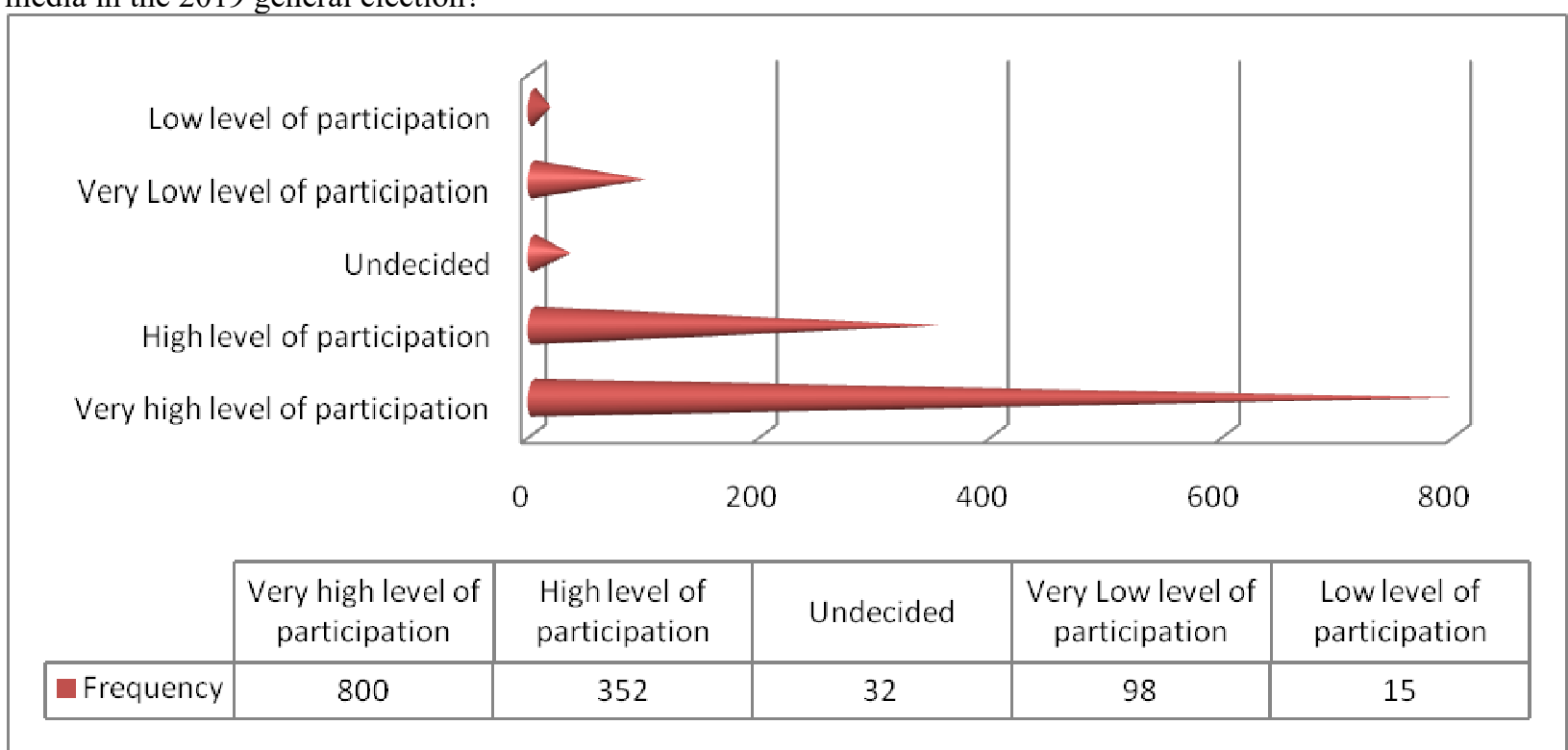

Figure 4: Respondents' level of the use of social media for participation in political communication

The data on Figure 4 is used to answer research question four. The research question sought to know the level of respondents' use of the social media for political participation. Likert scale was also use to get the responses from the respondents. $800(61.7 \%)$ and $352(27.1 \%)$ of the respondents said they used the social media on a very high level and high level respectively for participation in political communication in the 2019 general election in Nigeria. $32(1.2 \%)$ were undecided. Contrarily, $98(1.2 \%)$ and $15(1.2 \%)$ of the respondents said they used the social media on a low level and very low level for participation in political communication during the said election. We can draw conclusion from this finding that most voters in Delta State used the social media for participation in political communication during the 2019 general election in Nigeria. The finding also lays credence to the findings of the Stroud (2008); Galloway and Guthrie (2010); Fenton and Barassi (2011); Siluveru (2015); Van Dijck (2013); Arshad and Hassan (2014); Bode, et al (2014) and Garrett (2019); which postulates that that there is high level of social media usage by voters for participation in political communication.

Research question five: What is the level of participation of voters in Delta State in political communication through the social media in the 2019 general election compared to their political communication through the mainstream media in previous elections? 


\section{Level of participation in political communication while using the social media and during their usage of mainstream media}

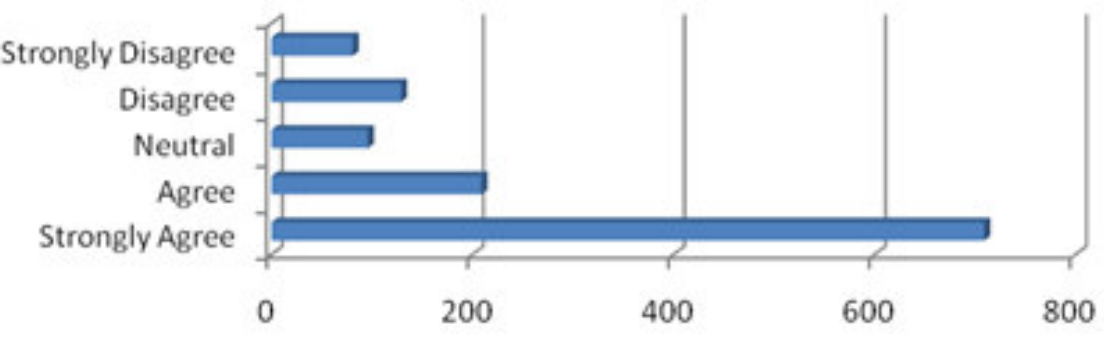

Figure 5: Level of respondents' participation in political communication while using the social media and during their usage of the mainstream media

Figure five above provides graphic details of the answer to the research question. Research question five is concerned with the level of the respondents' usage of the social media for political communication in the 2019 general election in Nigeria and their level of usage of the mainstream media for political communication in previous elections. They were asked to respond to a Likert scale of five items. The result shows that $782(60.3 \%)$ and $209(16.1 \%)$ of the respondents strongly agreed and agreed respectively that they used social media for political communication in the 2019 general election in Nigeria more than they used the mainstream media for participation in political communication in previous elections. A total of $96(9.9 \%)$ respondents said they were undecided while $129(9.9 \%)$ and 81 (6.2\%) respondents disagreed and strongly disagreed respectively, implying that they used more of the mainstream media for political communication in previous elections than they did through the social media in the 2019 general election in Nigeria. We could therefore deduce that majority of voters in Delta used the social media for political communication during the 2019 general election more than they used the mainstream media for the same purpose in previous elections. This finding reaffirms previous findings. Such findings include the ones by Fenton, (2011); Oyebode (2014); McAllister (2015); Okeke, et al (2016) and Freedom House (2017) which hold that most voters prefer participating in political communication through the social media to do so through the mainstream media.

As discussed earlier under the theoretical framework, the Technology Acceptance Model used for this study explains how users come to accept and use a technology based on perceived usefulness and ease-of-use of the technology. The findings from this study further confirm the postulations of the Technology Acceptance Model to the extent that the voters found the social media useful and easy and to use. This possibly accounts for their high exposure to the political communication in social media and their very favourable perception of political communication in the social media. The respondents' very high usage of the social media for political communication is another attestation to this study's reaffirmation of the tenets of the theory. The theory is therefore adopted for this study.

\subsection{Summary and Conclusion}

The study was designed to interrogate the extent of the social media by the electorate in Delta State Nigeria to participate in the 2019 general election in Nigeria. The popular impression before the 2019 general election was that the voters were silenced from participating effective in political communication during election because they had limited or no access to the mainstream media. Five research questions were therefore formulated to aid this study. The results indicate that the voters in Delta State sufficiently exposed to political communication in the social media during the said election. We also conclude, based on the findings, that the voters in Delta State had very favourable perception of the social media as good means of political communication during the 2019 general election. They also used the social to participate effectively in political communication and discourse during the said election. From the findings we also conclude that the voters in Delta State prefer the use of the social media to the mainstream media for participation in political communication during the 2019 general election. Additionally, the study concludes that voters in Delta State participated in political communication through the use of the social media during the said election more than through the mainstream media in previous elections. We therefore conclude that voters in Delta State deployed and used the social media effectively for participation in political discourse during the 2019 general election in Nigeria. 


\section{Recommendations}

We make the following recommendations

1. that the voters should sustain their exposure to the use of the social media for political participation so that can also be kept abreast of the happenings in the political terrain;

2. the voters should continue to use the social media to interrogate political leaders, election candidates during elections and after the election period;

3. Politicians take advantage of the social media usage by the electorate to communicate effectively and credibly with the electorate.

\section{References}

Adamu. A. (2018). The role and use of social media in elections campaigns and voting behavior in Nigeria: An analysis of 2015 presidential election. International Journal of Recent Innovations in Academic Research. 2(6), 117-129

Adegbola, O and Gearhart, S. (2019). Examining the Relationship Between Media Use and Political Engagement: A Comparative Study Among the United States, Kenya, and Nigeria. International Journal of Communication 13,1231-1251 Africa. Global Media Journal, 12 (22), 1-20.

Arshad, A., Hassan, S. A. (2014). Role of new media in political discussion and changing voting behavior of university students. International Research Journal of Social Sciences, 3(7), 4-9

Assibong, P. and Oshanisi, O. 2018. The Role of Information and Communication Technology (ICT) in the 2015 Presidential Election of Nigeria. Journal of Culture, Society and Development, 38: 1-7.

Ayeni, T.P. and Esan, A.O. (2018). The Impact of ICT in the Conduct of Elections in Nigeria. American Journal of Computer Science and Information Technology, 6(1): 1-6.

Bagozzi, R.P. 2007. The legacy of the technology acceptance model and a proposal for paradigm shift". The Journal of Association for Informatioin System. 8.4: 244-254.

Bello, B, Inuwa-Dutse, I and Heckel, R. (2019). Social Media Campaign Strategies: Analysis of the 2019 Nigerian Elections. Sixth International Conference on Social Networks Analysis, Management and Security (SNAMS), Retrieved February 23, 2020 from https://ieeexplore.ieee.org/stamp/stamp.jsp

Biswas, A, Ingle, N and Roy, M. (2014). Influence of Social Media on Voting Behavior. Journal of Power, Politics \& Governance. 2(2), 127-155

Bode, L, Vraga, E.M., Borah, P and Shah, D.V. (2014). A New Space for Political Behavior: Political Social Networking and its Democratic Consequences. Journal of Computer-Mediated Communication (19) 414429

Brants, K. and Voltmer, K. (2011). Introduction: Mediatization and de-centralization of political communication (pp,1-15) in K. Brants \& K. Volmer (Eds) Political communication in Postmodern democracy: Challenging the primacy of politics. U.K. Palgrave

Chadwick, A. (2013). Hybrid media system: Politics and power. Oxford: Oxford University Press

Chan, M. (2016). Social network sites and political engagement: Exploring the impact of Facebook connections and uses on political protest and participation. Mass Communication \& Society, 19, 430-451.

Chijioke, O. (2013). Social media. In Okoro, N. (Ed.) Contemporary readings in media and communication studies. Enugu: St Benedette Publishers Ltd.

Dagona, Z. K., Karick, H., \& Abubakar, F. M. (2013). Youth participation in social media and political attitudes in Nigeria. Journal of Sociology, Psychology and Anthropology in Practice. 5(1), 1-7.

DiFonzo N, Beckstead JW, Stupak N, Walders K. (2016). Validity judgments of rumors heard multiple times: the shape of the truth effect. Social Influence. 11(1):22-39.

Egwemi, V. (2013). Issues in the 2011 general elections in Nigeria: An introduction. In Egwemi, V. (Ed.). Issues in the 2011 General Elections in Nigeria. Ibadan: Sm-Adex Printers.

Emmer, M., \& Kunst, M. (2018). "Digital citizenship" revisited: The impact of ICTs on citizens' political communication beyond the western state. International Journal of Communication, 12, 2191-2211.

Emruli, S., \& Baca, M. (2011). Internet and political communication- Macedonian case. International Journal of Computer Science Issues. 8 (3), 154-163.

Ezeah, G. \& Gever, V.C (2015). Emerging trends in political communication. In O. Ike \& Udeze, S. (Eds) Emerging trends in gender, health, and political communication in Africa. (pp, 145-165) Enugu: Rhyce Kerex

Fenton, N and Barassi, V. (2011). Alternative Media and Social Networking Sites: The Politics of Individuation and Political Participation. The Communication Review, 14:179-196, 2011

Freedom House. (2017). Freedom of the press 2017. Retrieved on 23 January from https://freedomhouse.org/report/freedom-net/freedom-net-2017

Garrett, R.K. (2019) Social media's contribution to political misperceptions in U.S. Presidential elections. PLoS ONE 14(3): e0213500 
Gerodimos, R., Justinussen, J. (2014). Obama's 2012 Facebook campaign: Political communication in the age of the like button. Journal of Information Technology \& Politics, 12, 113-132.

Golan, G. J., Arceneaux, P. C., Soule, M. (2019). The Catholic Church as a public diplomacy actor: An analysis of the pope's strategic narrative and international engagement. The Journal of International Communication, $25,95-115$.

Gottfried, Jeffrey, and Barthel, Michael. (2018). "Almost seven-in-ten Americans have news fatigue, more among Republicans." Retrieved on January 20, 2020 from: Washington, DC: Pew Research Center. Retrieved on 19 January from http://www.pewresearch.org/fact-tank/2018/06/05/almost-seven-in-tenamericans-have-news-fatigue-more-among-republicans/.

Hindman, Matthew. 2018. The Internet Trap: How the Digital Economy Builds Monopolies and Undermines Democracy. Princeton, NJ: Princeton University Press.

Ingram, David. 2018. "Pocket partisans: Campaigns use text messages to add a personal touch." NBC News. Retrieved on January 20, 2020 from: https:/www.nbcnews.com/tech/tech-news/sofas-ipads-campaignworkers-use-text-messages-reach-midterm-voters-n915786.

Johansson, E. (2019). Social media in political communication A substitute for conventional media? In Karl Magnus Johansson \& Gunnar Nygren (eds.) Close and Distant: Political Executive-Media Relations in Four Countries, pp. 149-174. Göteborg: Nordicom

Kahne, J., Middaugh, E., Allen, D. (2014). Youth, new media, and the rise of participatory politics. Youth and Participatory Politics Research Network, 1, 1-25.

Kalyango, Y., \& Adu-Kumi, B. (2013). Impact of social media on political mobilization in East and West Africa. Global Media Journal, 12 (22), 1-20.

Kushin M, Kitchener K (2009) Getting political on social network sites: Exploring online political discourse on Facebook. First Monday 14(11)

McAllister, I. (2015, 27-28 May). Internet use, political knowledge and political participation among young voters in Australia. The Conference Democracy: A Citizen Perspective, Åbo Akademi University, Turku, Finland.

Nwanton, A. K., Odoemalamn, C. C., Orji-Egwu, A., Nwankwo, U. S., \& Nweze, S. (2013).

Social media and political participation in Africa: Issues, challenges and prospects. In D. Wilson (Eds.), Communication and the New Media in Nigeria: Social engagements, political development and public discourse (pp. 64-84). African Council for Communication Education.

Ohme, J. de Vreese, H. Albaek, E. (2017).The uncertain first-time voter: Effects of political media exposure on young citizens' formation of vote choice in a digital media environment. New Media and Society, https://doi.org/10.1177\%2F1461444817745017

Okeke, C. Chinonye, F. and Obi, I. (2016). Social Media As A Political Platform In Nigeria: A Focus On Electorates In South-Eastern Nigeria. Journal of Humanities And Social Science (IOSR-JHSS) 21(11)06-22

Okoro, N. \& Kenneth, A. N. (2013). Social media and political participation during the 2011 general elections; The lapses and the lessons. Global Journal of Arts Humanities and Social Sciences. 1(3), 29- 46.

Okoro, N. \& Santas T. (2017). An Appraisal of the Utilisation of Social Media for Political Communication in the 2011 Nigerian Presidential Election. African Research Review: an International Multi-Disciplinary Journal, Ethiopia, 11 (1),115-135.

Oyebode, M.O. (2014). Use and misuse of the new media for political communication in Nigeria's Fourth Republic. Developing Countries Studies. 4 (4), 92-102.

Rohlinger, Deana A., and Bunnage, Leslie. 2017. Did the Tea Party movement fuel the Trump train? The role of social media in activist persistence and political change in the 21 st century. Social Media + Society 3(2).

Sauter,T, \& Bruns, A., (2013). Exploring Emotions on \#auspol: Polarity, Conservativism and Public Performance in the Twitter Debate on Australian Politics. Selected Papers of Internet Research, 14

Siluveru, M. (2015). Social and digital media in political communication. International Journal of Scientific Research, 4, 768-770

Stroud, N. J. (2008). Media Use and Political Predispositions: Revisiting the Concept of Selective Exposure. Journal of Political Behaviour, 30(3), 341-366.

Tandoc, E. C., Lim, Z. W., \& Ling, R. (2018). Defining “fake news”. Digital Journalism, 6(2), 137-153.

Tesler M, Zaller J. (2017) In: Jamieson KH, Kenski K, (eds) The Power of Political Communication. Oxford: Oxford University Press. p. 69-84.

Udeajah, R., \& Gever, V. C. (2015). Social media usage as correlate of reading habit among Secondary school students: Implication for policy formulation. International Journal of Educational Research, 14, (4), 158165.

Ugwuanyi, C.J Olijo, I. I and V.C, Gever. (2019). Social Media as Tools for Political Views Expressed in the Visuals Shared among Social Media Users Library Philosophy and Practice 2595. https://digitalcommons.unl.edu/libphilprac/2595. 
Van Dijck, J. \& Poell, T. (2013). Understanding social media logic. Media and Communication, 1(1): 2-14

Van Dijck, José. 2013. The Culture of Connectivity: A Critical History of Social Media. New York: Oxford University Press.

Wattal, S., Schuff, D., Mandviwalla, M., \& Williams, C. (2010). Web 2.0 and politics: the 2008 U.S. presidential election and an e-politics research agenda. $M I S Q$, 34(4), 669-688

Yardi S, Boyd D (2010) Dynamic debates: an analysis of group polarization over time on twitter. Bull Sci Technol Soc 20:1-8

Zeng D, Chen H, Lusch R, Li S (2010) Social media analytics and intelligence. IEEE Intell Syst IEEE Intell Syst 25(6):13-16

Zhang W, Johnson TJ, Seltzer T, Bichard S (2010) The revolution will be networked: the influence of social networking sites on political attitudes and behavior. Soc Sci Comput Rev 28:75-92

\section{Acknowledgements}

No individual or organization sponsored this studied. I did personally. Meanwhile, I thank Dr. Callistar Obi, the Director of Centre for Continuing Education of the Delta State University, Abraka, for guiding me on some areas of data processing. I also thank the research assistants. 